\title{
Agrorecreational ecoparks in the quarries territory as a new type of urban production (on the example of Kryvbas)
}

\author{
Taras Rudenko' ${ }^{1}$, Tetiana Mukha ${ }^{2}$, Mariia Rudenko ${ }^{3}$ \\ ${ }^{1}$ Department of Buildings Architecture and Urban Planning, Section of Architecture of Buildings and \\ Structures, Poltava National Technical Yuri Kondratyuk University, Ukraine, \\ e-mail: rudenkoforwork@gmail.com \\ ${ }^{2}$ Department of Buildings Architecture and Urban Planning, Section of Urban Planning, \\ Poltava National Technical Yuri Kondratyuk University, Ukraine, \\ e-mail: tanya.mukha.85@mail.ru \\ ${ }^{3}$ Department of Buildings Architecture and Urban Planning, Section of Architecture of Buildings and \\ Structures, Poltava National Technical Yuri Kondratyuk University, Ukraine, \\ e-mail: rudenko.formail@gmail.com
}

\begin{abstract}
The article analyzes the main conditions of formation of agrorecreational ecoparks in the quarries territory, which no longer perform their initial functions. Agrorecreational ecoparks are regarded as a new type of urban development in combination with recreational function for industrial cities. Thus agrorecreational ecoparks are researched as structural elements of both agroproductive and recreational complexes of a country. Depending on types of activity there have been established main functional subzones and their interposition according to the exploitation mode and territory security. The planning structure of an agrorecreational ecopark locates the subzones of scientific use in the middle of a park, in the most accessible places as they are main attraction for visitors. Natural landscape of recreational use subzone adjoins the scientific zone; service centers and utility zones are located along the edges of the park thus creating a buffer area. The main groups of relief forms have been analyzed, which directly affect the planning structure of the researched parks. The main types of agrorecreational ecoparks in terms of relief forms have been identified; dimensional and spatial peculiarities of organization of such territories have been determined. In the context of a complex terrain and intensive soil erosion the major component of agrorecreational ecoterritories is geoplastic relief with drainage network (columbine), which determines precipitations run-off and the water regime of the park in general. The main notions and special features of landscape columbine and geoplastics (terracing) have been analyzed. The major types of agrolandscapes under the conditions of agrorecreational ecoparks formation have been established.
\end{abstract}

Keywords: agrorecreational ecopark, relief, geoplastics, landscape columbine, agrolandscape, derelict lands, quarries.

\section{Introduction}

Such industrial cities as Dniprodzerzhynsk, Kryvyi Rih, Zhovti Vody etc. can be found in the modern territory of Ukraine, where there are hazardous industries (extraction of iron ore and manganese ore, mechanical engineering, metallurgy etc.). In the given article the term "hazardous" is applied not only to transfer the meaning of hazard for 
population health but also danger for transport infrastructure and urban zoning as the combination of these factors affects the quality of people's lives. Therefore, the increase of life quality in industrial cities is an actual issue nowadays. The definition of "Kryvbas" in this article refers to the Kryvyi Rih mining-ore region and contains industrial purpose territories in Kryvyi Rih city and surrounding areas.

Kryvyi Rih is one of the problematic cities in Ukraine, whose population is about 1 million people. There are deposits of iron ore in its territory, which are not going to be depleted for another 100 years. So in that future period the population is predicted to experience ecological problems connected with the extraction and processing of iron ore. Until 1990s the city was developing and growing together with the population increase but now the amount of residents is quite stable. This fact can also be detected through the performance index of residential areas construction. Despite the low figures of residential construction, the city experiences high dynamics of recreational zones improvement, public construction and modernization of industrial complexes.

Kryvyi Rih is the longest city in Ukraine and Europe. Its length is $126 \mathrm{~km}$. Despite this "leadership", the city faces a number of urban problems such as low building density, long stretch of roads, territorial isolation of districts and residential neighborhoods, excessive polycentricity of territorial developments. It is connected with the particular industrial constituent of the city. Metallurgical enterprise "Arselor Mittal Kryvyi Rih" and other secondary companies occupy a large part of the city area and derelict lands (quarries, dumps), the majority of which is under development. Residential areas are found side by side to industrial ones, for this reason the structure of Kryvyi Rih has such specific characteristics.

In these strategic territorial units in connection with high amount of derelict lands Ukraine has preconditions for development of recreational zones in industrial cities where the natural and man-made resources are found.

Ukraine has a high potential in agricultural sphere due to the combination of geological, territorial and climatic conditions. Food production takes one of the leading positions in the economy of the country. Thus, the introduction of a new type of manufacturing and recreational park (agrorecreational ecopark) is a logical step in the development of food production in Ukraine and is a solution to the problems of derelict lands in industrial cities.

Agrorecreational complexes of population centres are of great importance for the system of recreation in Ukraine. Reproduction and conservation of natural resources must be based on the security of resorts and recreational zones and on the transformation of derelict lands into usable recreational units. Despite the obvious ecological problem in the development of agrorecreational complexes, the figures of reserve areas for the development of agrorecreational ecoparks in populated areas and beyond have not been identified. Agrorecreational ecoparks should be considered as structural elements of both agromanufacturing and recreational complexes of the country. There is a need in a more thorough research of such issues as ecological, economic and city-planning potentials of agrorecreational ecoparks in the territories of industrial cities.

\section{The review of the most recent research and publications sources}

Architectural and planning organization of agrorecreational villages (on the example of forest-steppe zones of Ukraine) is researched in the PhD thesis of Kodin V.O. [1]. The doctoral dissertation of V.V. Shulyk [2] analyzes the problems of the current condition from the perspective of a systematic approach, looks into the features of a systematic 
organization and provides recommendations on development of recreational systems spatial structure in urban planning field of Ukraine. The features of formation, structure and tendency of agrorecreational complexes development (on the example of Lviv region) are researched in the PhD thesis of I.G. Pandyak [3]. Kazakov V.L. [4] in his scientific study looks into the features of man-made landscape complexes of Kryvbas and the ways of their rational use and conservation. Features of mining rehabilitation, restoration and recultivation are studied in detail in the scientific works of Turkish researcher Kuter Nazan [5]. Properties of Limestone quarry reclamation in Britain described in academic papers of British researchers J. GunnD and Bailey [11]. Investigation of the quarries territories using for agricultural purposes possibility were conducted by Chinese scientists Hong Quan and Tang Huichao [12]. Practical methods of organic farming features using is considered in works of Austrian consultant for natural agriculture Sepp Holzer. The author developed the basic principles of ecological parks in different relief conditions. He explores features of creation self-sustaining crater garden with permaculture principles using [15].

\section{The main material and results}

Recreation (Polish "Rekreacja" - rest, from Latin "recreatio" - restoration) - rest and repair of human health lost after work. Recreational resources are the combination of natural and man-made units and phenomena which can be exploited for rest, treatment and tourism. The natural resources include warm seacoasts, river banks, lakes and water storage reservoirs, woodland and meadows, foothills and mountains. Man-made resources encompass capital and historical centres, city resorts or places of public resorts, religious complexes, fortification constructions and others located beyond population centres, derelict lands of manufacturing and industrial activity which are suitable for restoration and transformation into agrorecreational ecocomplexes.

Expansion of land areas for recreation has taken place in recent years. Agrotourism is becoming especially important. Territorial organization of agrotourism is a system of spatial interlocation of population centres, which provide agrorecreational services for each other and for cities with the consumers of agrotouristic services [6].

Agrorecreational ecoparks play significant part in the general system of planting, which is very important for industrial regions. To a large extent they are the protection sites and nature restoration sites of general and special recreational use. The territory of agrorecreational ecopark can be divided into subzones according to the usage regimes and premises security: subzones of scientific use - exemplary facilities, agrolandscape; subzones of recreational use - natural landscape, organizational landscape; subzone of pedestrian and transportation links.

One of the advantages of agrorecreational ecoparks is manufacturing, which can take place without the limitation of resources. For industrial cities agrorecreational parks are the first step to ecologization of environment and an additional way of city manufacturing development after the decrease of mineral resources deposits in sites. Since there are a low number of tourist attractions in Kryvyi Rih, alternative kinds of tourism and recreation start to be developed (industrial tourism, recreation in man-made zones, individual agrorecreational activity in country houses). In such a way the introduction of a peculiar type of tourism - agrotourism will have a positive effect on the development of a recreational system in the city.

Kryvorizhzhya quarries are typical recreational places for population and adjoining territories are used for individual agrorecreational activities [4]. Currently these two functions are independent but if to combine them by creating agrorecreational ecopark, it is 
possible to solve the problem of recreational territories disorganization. Zoning and rationalization of recreational territories enables to create attractive environment for those having a rest.

Agricultural production in agrorecreational ecoparks affects the decrease of agricultural products expenses and the increase of agroproduction economic effectiveness. Thus agrorecreational ecoparks can be regarded as industrial units as they are closely connected with food production.

Zoning of agrorecreational ecoparks is accomplished in different ways depending on nature conditions, territory area, program of acceptable scientific, recreational and agricultural use.

The planning structure of an agrorecreational ecopark usually locates the subzones of scientific use in the middle of a park, in the most accessible places as they are main attraction for visitors. Natural landscape of recreational use subzone adjoins the scientific zone, service centers and utility zones are located along the edges of the park thus creating a buffer area. The pedestrian and transportation subzone consists of circular or transit roads, network of roads inside a park (main, operational, utility), landscape and route corridors as well as touristic and excursions roads. The circular road provides connection between planning zones of recreational regions; the main park road goes through the most picturesque places of agrorecreational ecopark and is designated for car traffic and coaches (for low land parks); the operational park road goes through park zones with limited traffic of excursion groups; the utility road is intended for the administrative transport which provides the territory maintenance [5].

Touristic and excursion roads can be executed by suspended ropeways while crossing hard-to-reach or protected parts of nature park or by vertical lifts for taking tourists to the viewpoints. Landscape and route corridors are determined by the location of unique nature objects and agrolandscapes.

The location of the above mentioned elements depends on a great number of factors, one of which is the relief. The relief of agrorecreational ecopark constitutes ecological and plastic landscape base and is the most stable component. With the help of current classifications $[7,8,9]$ and taking into account the features of landscape art $[10,13,14]$ the relief of agrorecreational ecoparks can be divided into three groups: positive forms relief, negative forms relief and neutral relief. The first group comprises the elements of landscape which are located above the nominally established point of zero reading. The second group consists of those elements, which are located below the nominally established point of zero reading. The third group encompasses the parts of low land relief with the slight incline (to $5-7^{\circ}$ ). Independent low land and low land of large area belong to the group. The process of territory study requires the detachment of small low land parts (horizontal areas), which are the constituents of positive forms (water-diving plateau), negative ones (ravine and quarry bottoms) and horizontal sites on slopes.

The application of this classification is allowed for objects of different sizes ranging from large agrorecreational ecoparks, which are created on such relief forms as river valleys, ravine systems, mountains, hills, large areas of derelict lands (and even combination of the forms) to small areas which are taken by elements of these forms or their artificial models. Relief forms are actively included in the dimensional structure of an agrorecreational ecopark and influence its space organization.

Agrorecreational ecoparks in the quarry territories can be included into the group of agrorecreational ecoparks which develop below the nominally established point of zero reading or on the slopes. At the same time such an agrorecreational ecopark develops on slopes (walls), quarry bottom and adjoining territories. Therefore, agrorecreational ecoparks 
in the quarry territories include types of agrorecreational ecoparks on low land relief and slopes.

Agrorecreational ecoparks on low land relief. Territories with slight and barely visible incline can be attributed to low land relief. Areas with zero or about zero incline do not have run-off and are peat lands. Smooth-faced surface is usually monotonous and is deprived of plastic picturesqueness. Main vertical and dimensional focuses are created with tree vegetation and geoplastic terraces and hillside beds. Dimensional and space variety of territories is created with the help of closed and half-open massifs, tree groups and open meadows which form landscape paintings. Inertness can be reduced by finding the smallest inclines, reinforcement of their geoplastics and their skillful inclusion in agrorecreational ecopark (Fig. 1).

Agrorecreational ecoparks on slopes (Fig. 2). Such a relief is often terraced, in such cases edges of the terraces are the most suitable spots for viewing the landscape and have utilitarian nature for agroprocesses. For this reason terraces have both rectilinear and free shapes which correspond to the directions of horizontals. Roads are laid on terraces or along the slope. The special feature of agrorecreational ecopark on rugged relief is either the use of current form of terraced derelict land or geoplastics and landscape water collection. It is worth mentioning that taking into account man-made origin of quarries, a part of engineer activities is already performed (terracing, road laying and utility supplies).

Under the conditions of rugged relief and intensive soil erosion the main component is geoplastic relief with drainage network (columbine), which determines precipitations run-off and water regime of the territory of agrorecreational ecopark. Depending on the slope orientation and water run-off direction, heat "traps" of artificial water reservoirs are created to form own micro climate on terraces (opening of terraces with heat "traps" is advisory for south directions). Thus it is important to take into consideration the features of landscape columbine very thoroughly.

a)

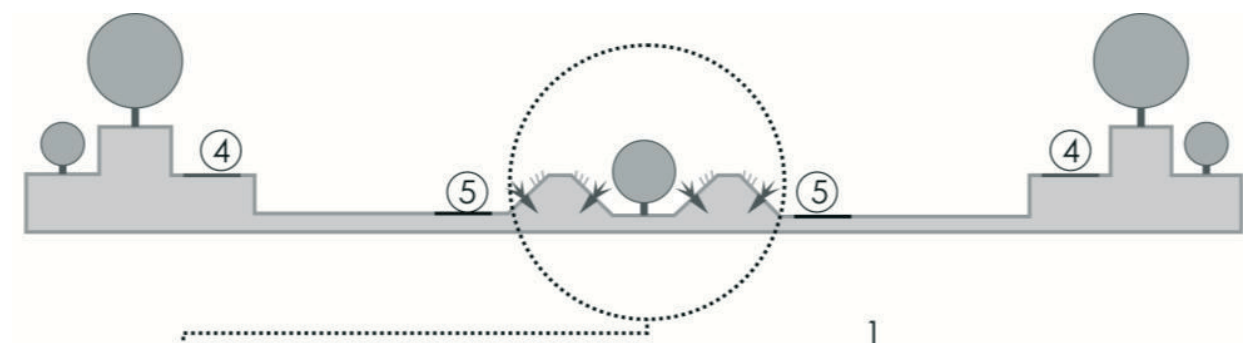

b)

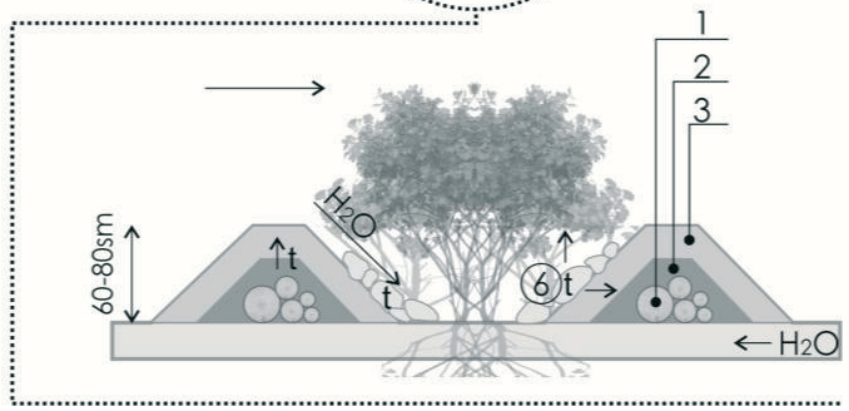

Fig. 1. Scheme of agrorecreational ecopark on low land relief: $a$ - general drawing, $b$ - drawing of hillside beds. 1- different organic material (branches, roots, grass etc.), 2 - meadow turf (with grass inside out), 3 - layer of humus, 4 - viewpoint paths on protected rock-fill terraces, 5 - utility paths 
a)

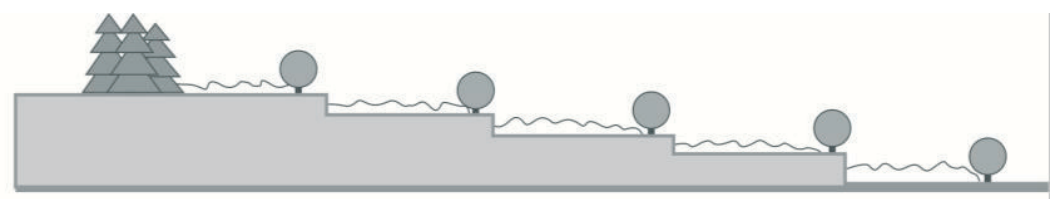

b)

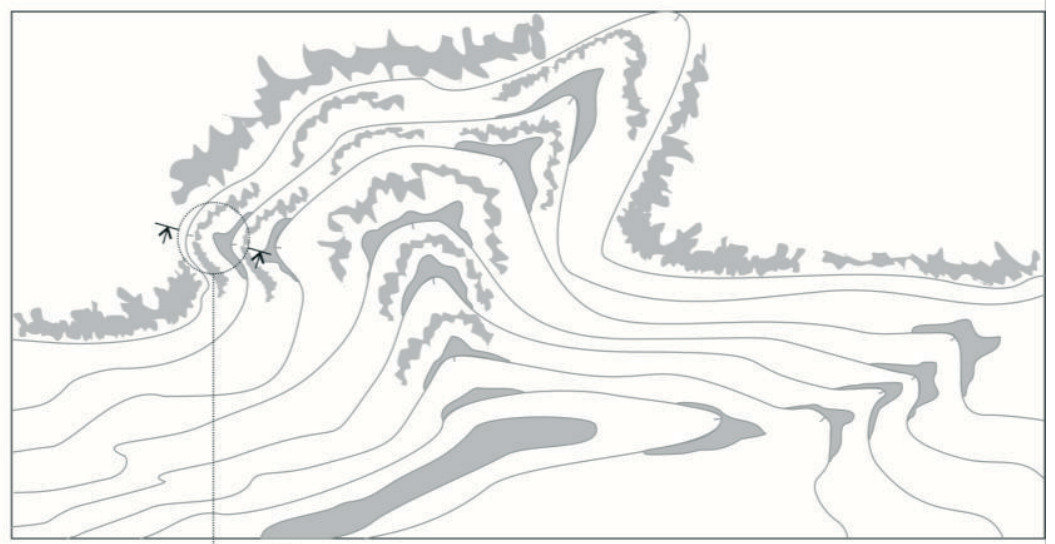

c)

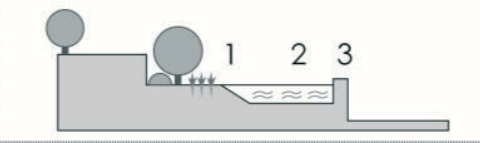

Fig. 2. Agrorecreational ecopark on a slope: a - general drawing of the park, $\mathrm{b}$ - general plan scheme, $\mathrm{c}-$ drawing of "heat trap". 1 - beds, 2 - water reservoirs on a slope, 3 - viewpoint path on a terrace

Landscape columbine is relatively closed and detached territory group which is characterized by similar erosion processes, micro climatic conditions and interconnections of measures to solve the problems of local nature balance. Other elements of low taxonomic level such as landscape belt, agrofacies, forest belt etc. are suitable for such structure.

Landscape and columbine approach determines six main types of agrolandscapes: plain landscape with low land type of territory, plain agrolandscape with cross-straight slope profiles, plain agrolandscape with disperse (gibbose) columbine, ravine and plain agrolandscape with columbines, ravine and plain agrolandscape with the totality of ravine offset, large bottom land in river valleys [7].

Agrolandscapes in the quarry territories can correspond to the types of given classification. Plain agrolandscape with disperse (gibbose) columbines with different exposition often has the form of arable land with interconnected parts of ravine land. Regimes created there (water, thermal, air) are distinguished by significant detachment and are characterized by common interconnected measures to regulate nature balance. Ravine and plain agrolandscape with accumulative columbines, which are limited with divide line. Precipitation run-off in the given category greatly influences water regime of the detached complex which is characterized by common interconnected measures to regulate nature balance. Ravine and plain agrolandscape is represented by totality of ravine detachments, joint slopes, hollows, cloughs which develop unified network of hydrography - "rumpled relief".

Geoplastics is one of the ways of relief plastic processing by creating its forms artificially taking into account aesthetic and functional demands of agrorecreational ecoparks. This method has existed in the landscape art for a long time (artificial terraces, hills, swells, amphitheaters, dams etc.) [7]. Nowadays technical level enables to perform earthwork on a large scale and to create any relief forms. 


\section{Discussion}

A number of architectural methods is used to take into account two main components (columbines and geoplastics) while forming agrorecreational ecoparks.

Depending on the direction and nature of melted water run-off, catch reservoirs are formed on terraces. This allows to coordinate and organize a columbine. This component mainly determines general look and micro climate of agrolandscape as groups of trees (fruit and non-fruit trees) and bushes are formed near every water reservoir so as to create heat "traps". Such an approach enables to grow even indistinctive for Kryvyi Rih region moderate climate fruits and vegetables. In such conditions fruits and vegetables that require sheltering in the winter can be grown. As an example may be mentioned: figs (Adriatic White, Verdone; Grosse Violette de Bordeau), peaches (Prunus persica var. nucipersica; Prunus persica var. persica), grapes (Vitis labrusca $\times$ Vitis vinifera, Vitis labrusca Isabella), laurel (Láurus nóbilis) etc. Landing in heat "traps" prolongs the fertile period of remontant varieties: strawberry (Fragaria chiloensis; Fragaria virginiana), raspberry (Rúbus idáeus, Rosaceae) etc. In Poltava National Technical Yuriy Kondratyuk University research in this scientific field were conducted. One of the results of such research is a project of agrorecreational ecopark (Fig. 3) designed for Central Ukrainian region on the base of department of buildings architecture and urban planning. There were given the names of crops for different tiers of terraced park. Plants are selected depending on its thermophilic and wind resistance characteristics. Upper tier is characterized by stronger winds. On the lower tier it is warmer and less windy. On the slopes of the downwind area wind speed is reduced by $10 \ldots 30 \%$ depending on the tilt angle and shape of the slope. For higher effectiveness heat "traps" can be created on south edges of quarries for better insulation. Other components (soil, flora etc.) cam play coordinating role in planning and designing the territories. Considering faults of geological composition of quarry soil, fill-up ground with high concentration of humus is rational on the territory.

Terracing of agrorecreational ecopark increases crop area, protects from wind, forms heat trap; its humid and warm climate creates ideal conditions for heat-loving plants and demanding types of vegetables. Due to step structure of mixed planting, symbiosis enforces its effect. For this purpose plants of different sizes are farmed together. Large plants protect smaller ones from the wind, hail or too much sunshine.

Terraced form of agrorecreational ecopark enables to reach ground waters. Due to capillary effect the moisture gets to the top. That is why agrorecreational ecopark is especially suitable for dry regions. After some time a pond can be formed on the territory of unwatered quarries depending on the level of ground waters inside agrorecreational park.

According to the principles of organic farming [15] plants support and protect each other when farmed in mix: sun-loving plants give shadows to sensitive ones, some plants grow from the wind side of others, plants with deep root system bring useful elements and water to the surface, which others need; if their branched root system decomposes it ventilates the soil and promotes further use.

It is sensible to foresee the opportunity to process the waste into biofertilizer in the territories not designated for tourists. It enables to economize funds for taking out the rubbish and purchase of stimulants for plants of biological origin.

Depending on production area of agrorecreational ecopark, market outlet can be oriented on visitors, can cover neighboring territories, the whole city and satellite towns.

Generally speaking, agrorecreational ecopark in the territory of industrial cities will have a positive effect on the system of recreational units and agroproductive sphere. Formation of agrorecreational ecopark will increase recreational area and will make it more organized especially in Kryvyi Rih. 


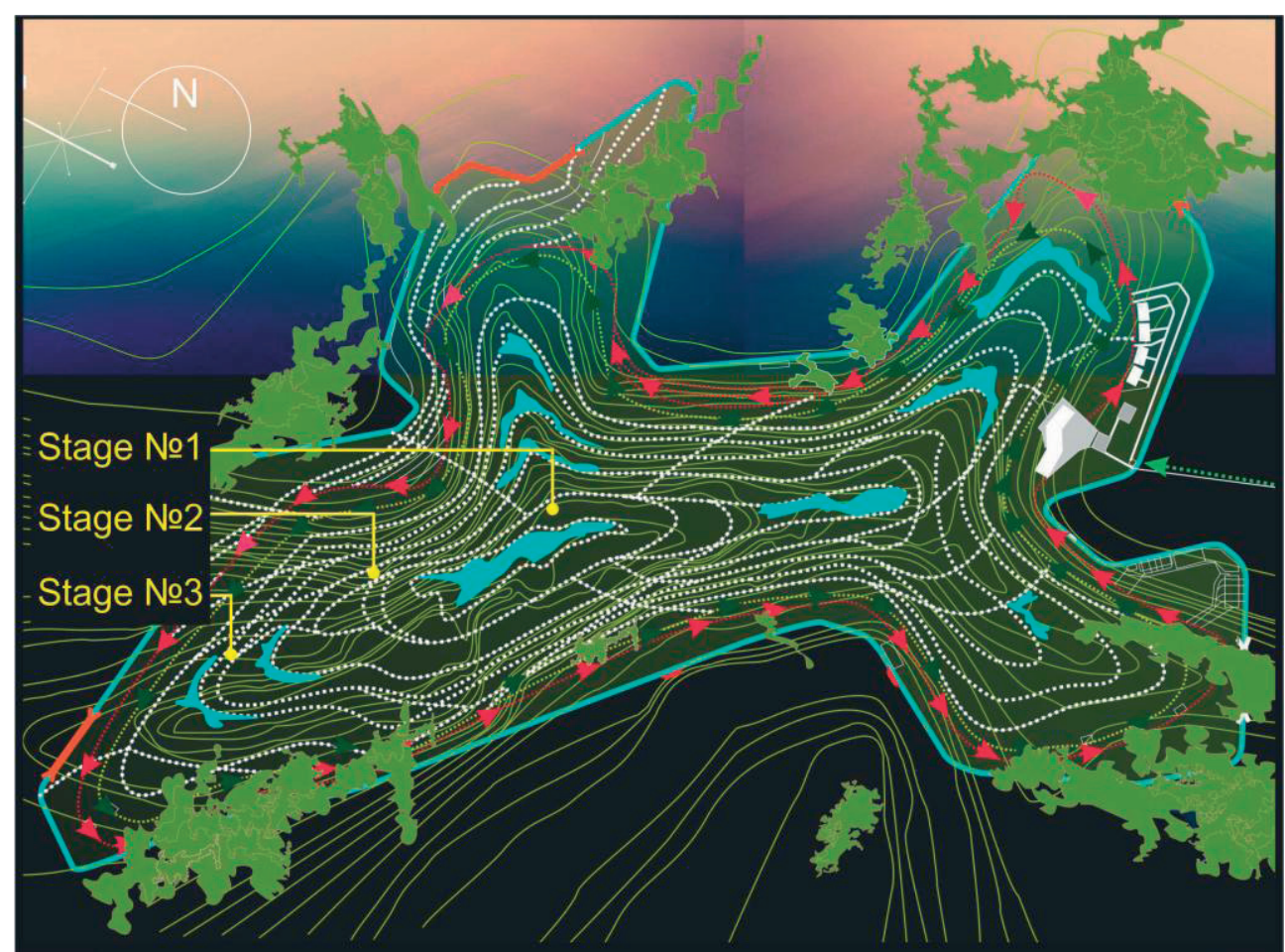

Planting material for stage №1

\begin{tabular}{|c|c|c|}
\hline \multirow{6}{*}{ 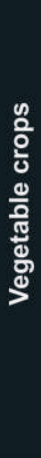 } & $\begin{array}{l}\text { Cucumber } \\
\text { (lat. Cucumis Sativus) }\end{array}$ & \\
\hline & $\begin{array}{c}\text { Chick peas } \\
\text { ( lat. Pisum) }\end{array}$ & \\
\hline & $\begin{array}{l}\text { Topinambour } \\
\text { (lat. Helianthus tuber osus) }\end{array}$ & \\
\hline & $\begin{array}{l}\text { Onion } \\
\text { (lat. Allium Cepa) }\end{array}$ & \\
\hline & $\begin{array}{l}\text { Tomato } \\
\text { (lat. Solanum Lycopersicum) }\end{array}$ & \\
\hline & $\begin{array}{c}\text { Corn } \\
\text { (lat. Zea Saccharata) }\end{array}$ & \\
\hline \multirow{2}{*}{ 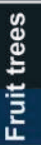 } & $\begin{array}{l}\text { Cherries } \\
\text { (lat. Prunus avi um) }\end{array}$ & \\
\hline & $\begin{array}{l}\text { Apple tree } \\
\text { (lat. Malus) }\end{array}$ & \\
\hline
\end{tabular}

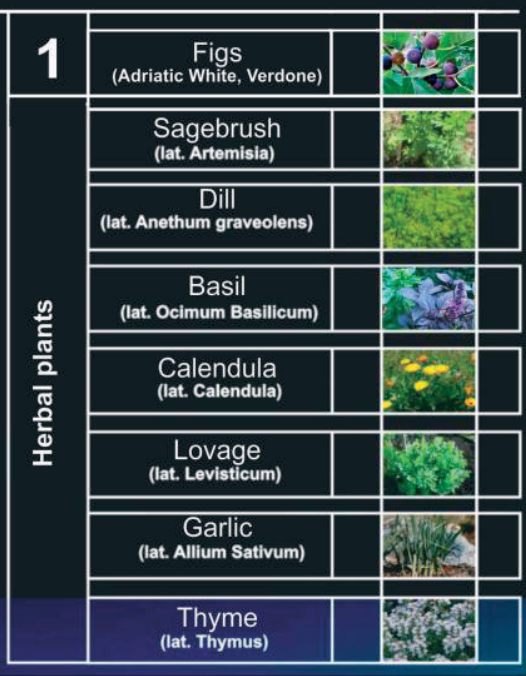

1 indistinctive for Kryvyi Rih region moderate climate plants

Fig. 3. Fragment of agrorecreational ecopark designed for Central Ukrainian region on the base of department of buildings architecture and urban planning project. Vasil Shulyk, Tetiana Mukha, Mariia Chukharko. 


\section{Planting material for stage №2}

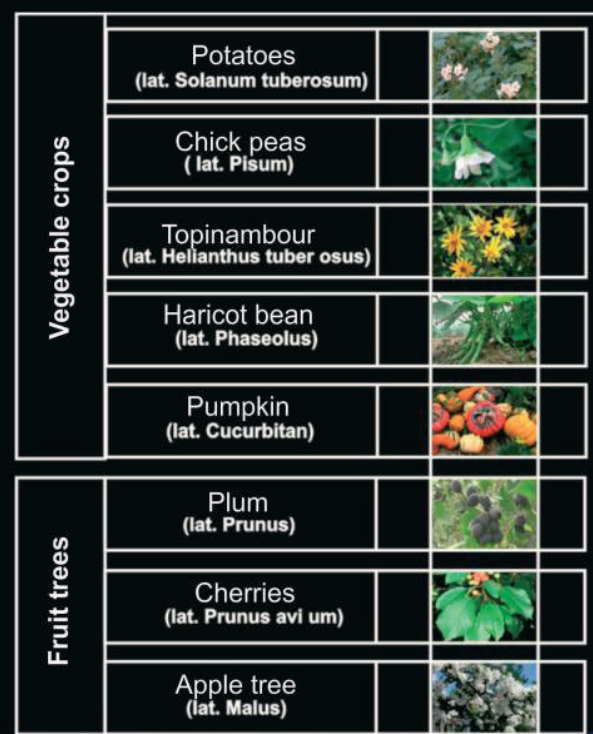

\section{Planting material for stage №3}

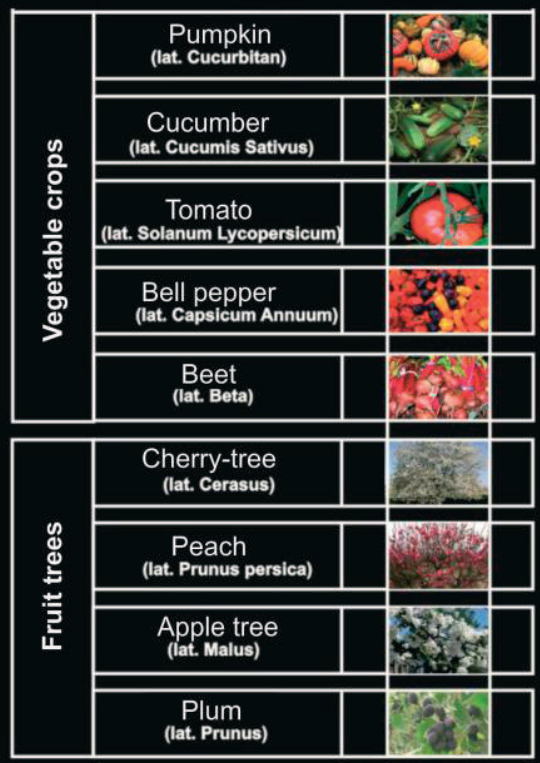

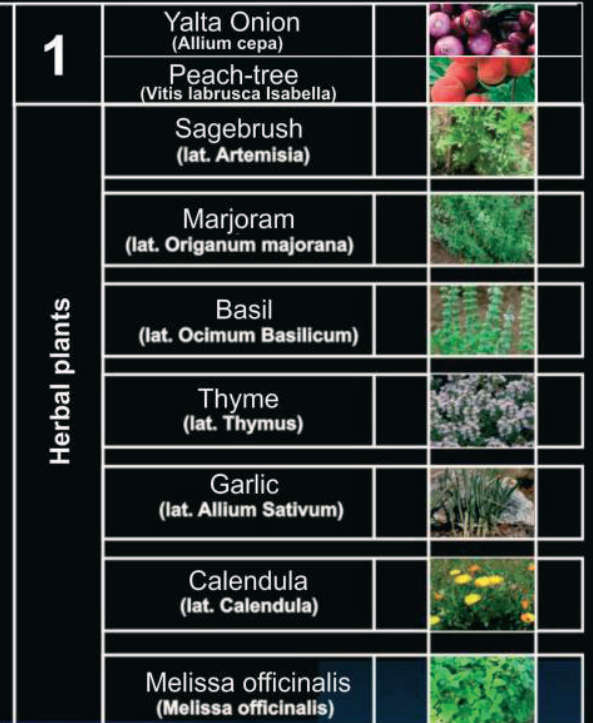

1 indistinctive for Kryvyi Rih region moderate climate plants

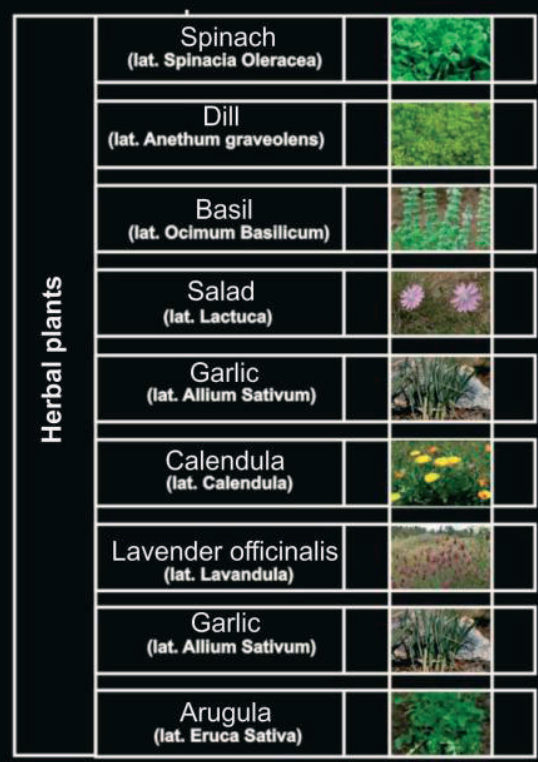

Fig. 3. continuation. Fragment of agrorecreational ecopark designed for Central Ukrainian region on the base of department of buildings architecture and urban planning project. Vasil Shulyk, Tetiana Mukha, Mariia Chukharko. 


\section{Conclusion}

The research has determined that the introduction of a new type of manufacturing and recreational park (agrorecreational ecopark) is a logical development of food production in Ukraine and a solution to problems of derelict lands in industrial cities.

Depending on activity types there have been identified main functional subzones in a park and their interlocation according to the regimes of use and protection of territories. The planning structure of an agrorecreational ecopark locates the subzones of scientific use in the middle of a park, in the most accessible places as they are main attraction for visitors.

Natural landscape of recreational use subzone adjoins the scientific zone, service centers and utility zones are located along the edges of the park thus creating a buffer area. The main groups of relief forms have been analyzed, which directly affect the planning structure of the researched parks. The identification of main types of agrorecreational ecoparks in terms of relief forms enables to draw a conclusion that agrorecreational ecoparks in the quarries territory can be referred to the group of agrorecreational ecoparks, which develop below the nominally established point of zero reading or on the slopes. At the same time such an agrorecreational ecopark develops on slopes (walls), quarry bottom and adjoining territories. Therefore, agrorecreational ecoparks on the quarry territories include types of agrorecreational ecoparks on low land relief and slopes.

Under the conditions of rugged relief and intensive soil erosion the main component of agrorecreational ecoterritories is geoplastic relief with drainage network (columbine), which determines precipitations run-off and water regime of the territory of agrorecreational ecopark in general. Taking into account man-made origin of quarries, a part of engineer activities is largely performed (terracing, road laying and utility supplies).

Generally speaking, the application of agrorecreational ecoparks in the territory of industrial cities will have a positive effect on the system of recreational units and agroproductive sphere. Formation of agrorecreational ecopark will increase recreational area and will make it more organized especially in Kryvyi Rih. In conclusion, agrorecreational ecoparks in the quarries territory can be defined as a new type of urban manufacturing not only for Kryvbas and Ukraine but also for similar derelict lands of other countries.

\section{References}

1. Kodin V. A. Architectural and Planning Organization of Agrorecreational Settlements (on the example of forest-steppe zone of Ukraine). autoabstract of Architecture PhD thesis 18.00.04, Kyiv, 1988.

2. Shulik V.V. Methodological Problems of Regional Recreational Systems Formation (on the example of Poltava region). autoabstract of Architecture $\mathrm{PhD}$ thesis 18.00.01, Poltava, 2001.

3. Pandyak I.G. Village Settlement in Lviv region: Features of Formation, Structure and Tendency of Development. autoabstract of Geography PhD thesis: 11.00.02, Lviv National Ivan Franko University, 2003.

4. Kazakov V.L. Man-made Landscapes of Kryvbas. Diversity of Landscape Complexes of Ukraine and Ways of Their Rational Use and Conservation: Methodology and Applicable Aspects. Collection of research papers, 41-46, 2000.

5. Nazan K. Reclamation of Degraded Landscapes due to Opencast Mining - Cankiri. Cankiri Karatekin University, 2012.

6. Luchenok S.A. Agrotourism. World Experience and Development in Republic of Belarus: monography, Minsk, publishing house BGEU, 2008.

7. Bogovaya I.O., Fursova L.M. Landscape Art. Moscow, Agpromizdat, 1988. 
8. Alexeyenko V.A. Geochemistry of Landscape and Environment. Moscow, Nedra, 1990.

9. Vergunov A.P. Architectural Composition of Gardens and Parks. Moscow, Stroyizdat, 1982.

10. Vergunov A.P. Landscape Design. Moscow: Vysshaya Shkola, 1991.

11. Gunn J., Bailey D. Limestone quarrying and quarry reclamation in Britain. Collection of research papers, 167-172, 1993.

12. Quan H., Huichao T. The application of restorative ecology to renovation of industrial wasteland. Collection of research papers, 611-614, 2009.

13. Lavlinskaya I.A. Methodology of Park and Garden Objects Formation (on the example of south Crimea objects). autoabstract of Architecture PhD thesis: 18.00.04 Urban Planning and Landscape Architecture, Simferopol, 2011.

14. Sokolskaya O.B., Teodoronskii V.S., Vergunov A.P. Landscape Architecture: Specialized Objects: study guide for university students, Moscow: publishing centre "Akademiya", 2008.

15. Holzer S. Desert or paradise. Publishing house "Zerno", 2012. 
